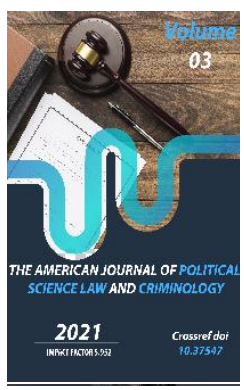

\title{
Deprivation Of The Right To Hold Certain Positions And Engage In Certain Activities In Foreign Legislation
}

\author{
Farkhod Sayfullaevich Alikulov \\ Tashkent State University Of Law, Theory And Practice Of The Application Of Criminal Law \\ Specialty Student, Uzbekistan
}

Journal Website: http://usajournalshub.c om/index,php/tajpslc

Copyright: Original content from this work may be used under the terms of the creative commons attributes 4.0 licence.

\section{ABSTRACT}

The comprehensiveness of the penitentiary system is central to achieving the goal of criminal punishment. In other words, no matter how perfect the type and system of punishment, if the mechanism of its application and execution is not implemented wisely, unfortunately, this punishment will remain ineffective. Deprivation of a certain right has a preventive character, which is clearly expressed as a punitive measure. The imposition of this penalty is mainly due to the need to prevent the recurrence of these crimes by persons who commit crimes related to the abuse of available opportunities in connection with their position or activities. It substantiates the relevance of the analysis of punishment in the form of deprivation of a particular right from the point of view of criminal law and criminal-executive law and the need to study it. This article reflects the specifics of punishment in the form of deprivation of certain rights in the criminal law of some foreign countries.

\section{KEYWORDS}

Punishment, criminal law, rights, code, responsibility, ban, article, deprivation.

\section{INTRODUCTION}

The issues of the application of punishments and other measures not related to deprivation of liberty are acquiring more and more pronounced international legal significance 
due to the fact that in many countries the urgency of the problems associated with overcrowding in penitentiary institutions is increasing. The VIII UN Congress on Crime Prevention (Havana, 1990) paid special attention to finding alternatives to isolating prisoners from society. It has adopted the UN Standard Minimum Rules for Non-custodial Measures, the so-called Tokyo Rules, which contain a set of basic principles to promote the use of non-custodial measures, as well as minimum guarantees for those to whom they apply [1, p. 48].

A similar regional document is the European Rules for the Application of Public (Alternative) Sanctions and Measures, adopted in 1992 by the Committee of Ministers of the Council of Europe, and other specialized international standards of this kind [2].

\section{THE MAIN RESULTS AND FINDINGS}

The United Nations Convention against Corruption provides for the establishment of procedures by which a public official charged with an offense established in accordance with this Convention may be duly removed, suspended from office or transferred to another position by an appropriate authority with taking into account the need to respect the principle of the presumption of innocence [3].

The Convention on Combating Bribery of Foreign Officials in International Business Transactions refers to civil or administrative sanctions applied to legal entities for the act of bribery of a foreign official. These may include temporary or permanent exclusion from the number of participants in public procurement or prohibition to engage in other commercial activities.
The International Covenant on Civil and Political Rights of the UN General Assembly in 1966 [4], along with the guarantee of the equal right of citizens and the possibility of equal access to public service, also provides for the right of the state to impose special duties and responsibilities. This right may be subject to certain restrictions, which, however, must be established by law and are necessary.

As we can see, the trend in the world criminal policy of recent decades is the expansion of the use of punishments that are not related to the isolation of the convicted person from society.

This affected not only the sphere of public relations, but also the sports industry. Thus, Article 10 of the International Anti-Doping Code "Sanctions against Individuals" contains the following provisions - the types of penalties are cancellation of the results of a sporting event (Article 10.1) and disqualification (Article 10.2).

It should be noted that there is an obvious analogy between the sanctions applied by the World Anti-Doping Agency (WADA) to antidoping rule violators with criminal penalties. At the same time, these measures represent an extrajudicial type of repression, are appointed without the consent and without the participation of the person brought to justice [5, p.p. 57-60].

In addition, deprivation of the right to hold certain positions and engage in certain activities is widely used abroad as measures of state coercion - additional punishment or additional legal consequences of committing a crime and is rightfully recognized as one of the most effective.

The criminal codes of European countries contain such types of prohibitions as, for example: 
a ban on driving a vehicle, deprivation of a permit to drive a vehicle (Criminal Code of the Federal Republic of Germany);

Deprivation of the right to hold office, the right to be elected and the right to vote (Criminal Code of the Federal Republic of Germany);

Ban on profession (Criminal Code of the Federal Republic of Germany);

Removal from office (Austrian Penal Code);

Deprivation of civil rights, which consists in the deprivation of the right to serve in the army of the Kingdom (the right to military service) forever or for a certain time (Austrian Penal Code) [6];

Deprivation of civil rights, deprivation of the right to vote on public issues (Norwegian Penal Code) [7];

Deprivation of academic degrees, titles, state powers, deprivation of the right to perform state functions, hold public positions or carry out public duties, deprivation of the right to be elected; to act as a jury, attested, etc .; carrying weapons, participating in the Civil Guard and serving in the army (Criminal Code of Belgium) [8].

Under US federal law, individuals convicted of corruption offenses such as bribery are deprived of the right to permanently hold certain positions or work for a specified period in certain industries [9, p. 45].

The model criminal code for the member states of the Union of Independent States under the deprivation of the right to hold certain positions or engage in certain activities means "the prohibition to hold positions in the civil service, in local government bodies, at enterprises of any form of ownership or in public associations, or to engage in certain activities" [10].

The question of the responsibility of convicts for evading punishment in foreign countries is resolved in different ways: 1) directly in the verdict, the court determines the type and amount of punishment to which the initial punishment will be replaced in case of evasion of the convict from serving it; 2) replacement of punishment for a more severe one; 3) mixed version; 4) the establishment of an independent composition of evasion (malicious evasion) from serving sentences.

Thus, liability for non-compliance with a courtordered ban is provided for in the General Part of the Criminal Code of the Republic of Poland as an independent crime (Article 244), followed by a fine, restriction of liberty or imprisonment for up to one year.

The Swiss Criminal Code establishes criminal liability under article 294 for violation of the ban on the profession (and Swiss criminal law provides for this type of ban as an additional penalty), with the sanction of arrest or a fine.

The criminal legislation of the Republic of Lithuania for evasion from serving sentences or punitive measures not related to imprisonment (with the exception of confiscation of property) establishes liability in the form of a fine or arrest (Article 243 of the Criminal Code of the Republic of Lithuania).

The French Criminal Code in Articles 434-40 and 434-41 provides for liability for evading punishment in the form of prohibition of professional or social activities, deprivation of a driver's license, prohibition on the possession or carrying of weapons. The sanctions for such an act are imprisonment for up to two years and a fine. 
According to $\S 145 \mathrm{C}$ of the German Criminal Code, in case of violation of the prohibition on the profession, such a person can be prosecuted and sentenced to imprisonment for up to one year or a fine.

Article 145 of the Dutch Penal Code establishes that a person who exercises a right, knowing that he is deprived of this right by a court decision, is punishable by imprisonment for up to six months or a third category fine.

In accordance with Article 306 of the Criminal Code of the Republic of Azerbaijan: malicious failure to execute a decision, sentence, ruling and court order that has entered into legal force is punishable by a fine of one thousand conventional financial units, or community service from 160 to 200 hours, or correctional labor for up to two years, or restriction of liberty, or imprisonment for the same period.

\section{CONCLUSION}

In cases where threat is manifested as an element of the objective aspect of another crime, it serves as a way and means to break the victim's resistance, to influence his psyche in order to intimidate him with this or that kind of injury if he does not comply with the guilt [11].

The study of the issue of deprivation of the right to hold certain positions and engage in certain activities in foreign legislation allows us to formulate the following conclusions:

1. In contrast to the Uzbek legislation, which provides for only one type - the deprivation of the right to hold certain positions or engage in certain activities, the codes of foreign states provide for an extensive list of criminal legal measures (basic or additional types of punishments, corrective and security measures, measures of a criminal legal nature, etc.) related to the deprivation of the right to hold certain positions, engage in a certain activity or profession, the right to vote and be elected, etc.

2. From the point of view of the sanctions applied by WADA to anti-doping rule violators, an obvious analogy should be noted with administrative and criminal punishment (disqualification, deprivation of the right to engage in certain activities). At the same time, these measures are an extrajudicial type of repression, they are appointed without the consent and without the participation of the person brought to justice.

3. A distinctive feature of these measures under foreign legislation is the long, compared to Russian, terms of deprivation or restrictions - the maximum period for most types of deprivation of certain rights is ten years, and in some cases for life.

4. Deprivation of the right to drive vehicles as a type of prohibition is enshrined in most of the criminal codes of European countries: in Germany as an additional punishment and a measure of correction and safety; in Italy - additional punishment; in England - a measure of a criminal law nature; in Spain a special security measure, etc.

5. In the UK Criminal Code, deprivation of the right to engage in certain activities can be used as an alternative to imprisonment, even when it is not provided for by the sanction of criminal law.

6. In most of the criminal codes of foreign countries, the legislator distinguishes between a prohibition on a profession and a prohibition on engaging in certain types of activities that are not related to the 
profession, giving them the status of independent punishments, with their purpose in different spheres of diminishing the rights of the guilty.

7. The issue of the state's response to the facts of evasion of the convicted person from serving the assigned punishment has been resolved in different ways: the presence of an independent corpus delicti; replacement by a more severe type of punishment when evading serving it; directly in the verdict, the court determines the type and amount of punishment to which the initial punishment will be replaced in the event the convicted person avoids serving it.

\section{REFERENCES}

1. Filimonov $\mathrm{O}$. Tokyo rules and the Russian practice of applying punishments not related to imprisonment // Criminal Law. - 2003. No. 2. - p. 48.

2. Recommendation No. R (92) 16 of the Committee of Ministers of the Council of Europe "On European rules on general sanctions and measures" (Adopted on 19.10.1992) // Collection of documents of the Council of Europe in the field of human rights protection and combating crime. - M.: SPARK, 1998 . - p.p. 123 - 124.

3. United Nations Convention against Corruption (adopted in New York on October 31, 2003 by Resolution 58/4 at the 51st plenary meeting of the 58th session of the UN General Assembly). [Electronic resource]. URL: http: www egov66.ru
4. Convention on Combating Bribery of Foreign Officials in International Business Transactions. OECD. Istanbul. November 21, 1997 [Electronic resource]. URL: http://ppt.ru

5. Kafiatulina A.V. Deprivation of the right to engage in certain activities in the norms of international law / A.V. Kafiatulina // Education. The science. Scientific personnel. - 2018. - No. 4. p.p. $57-60$.

6. Criminal Code of Austria / scientific. ed. S.I. Milyukov, translated from German by L.S. Vikhrova. - SPb. : Legal Center Press, 2004. - p.p. 67 - 68.

7. Norwegian criminal legislation / scientific. ed. Yu.V. Golik, translated from Norwegian by A.V. Beep. - SPb .: Yuridicheskiy tsentr Press, 2003 -- p.p. 38

8. Criminal Code of Belgium / scientific. ed. N.I. Matsnev, translated by G.I. Machkovsky. - SPb. : Legal Center Press, 2004. - p.p. $53-55$

9. F.V. Gabdrakhmanov Conviction for corruption crimes // Proceedings of the III All-Russian Scientific and Practical Conference (December 4, 2013). Kazan: Knowledge, 2013 -- p. 45

10. Model Criminal Code for the CIS member states (adopted by the resolution of the Interparliamentary Assembly of the CIS member states dated February 17, 1996) // Access from the reference - legal system "Garant".

11. Khudaykulov F. K. Force And Threat Of Violence Are As The Ways of Commission Of Rape: National And Foreign Experience //Psychology and Education Journal. - 2021. - T. 58. - №. 1. - C. $1123-1132$. 
The American Journal of Political Science Law and Criminology (ISSN - 2693-0803)

Published: April 30, 2021 | Pages: 88-93

Doi: https://doi.org/10.37547/tajpslc/Volume03Issue04-14

12. Алланова А. А. ЕВРОПА ДАВЛАТЛАРИ

ВА АМЕРИКА ҚЎШМА ШТАТЛАРИДА ҚОНУНГА ХИЛОФ РАВИШДА ДАВЛАТ ЧЕГАРАСИДАН ЎТИШ БИЛАН БОҒЛИҚ ЖИНОЯТЛАР УЧУН ЖАВОБГАРЛИК МАСАЛАЛАРИ //«Хуқуқий тадқиқотлар» электрон журнали. 2020. - T. 8. - №. 5 . 